S. Khalatur,

Doctor of Economic Sciences, associate professor, Professor of Finance, Banking

and Insurance Department, Dnipro State Agrarian and Economic University

ORCID ID: 0000-0001-8331-3341

D. Makbynia,

Student of gr. MGFBS-1-18, Dnipro State Agrarian and Economic University

ORCID ID: 0000-0002-2543-1371

\title{
IMPROVEMENT OF FINANCIAL RESOURCES MANAGEMENT IN AGRICULTURAL ENTERPRISE
}

\author{
С. М. Халатур, \\ А. е. н., доцент, професор кафедри фінансів, банківської справи та страхування, \\ Аніпровський державний аграрно-економічний університет \\ А. В. Махиня, \\ студентка гр. МгФБС-1-18, Аніпровський державний аграрно-економічний університет
}

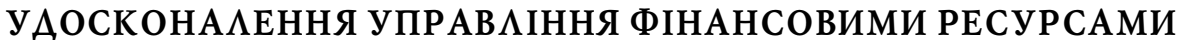 СІАЬСЬКОГОСПОААРСЬКОГО ПІАПРИЕМСТВА}

This article reveals the issues that arise in the management of agricultural enterprises. Methods and techniques of financial resources management of the enterprise and their improvement by means of planning, analysis, budgeting, crediting are demonstrated. The essence and importance of the financial service in an agricultural enterprise as a separate management body, which takes over the management of financial flows and solving various issues related to the financial activity of an agricultural enterprise, is disclosed by not only scientists but also private business owners who are looking for ways to improve the efficiency of their businesses. With regard to agricultural enterprises, it is determined that the activity of these enterprises has certain features: uneven production, seasonality and dynamic changes. Some regions have differences in the availability of territorial resources, geography of demand, and the number of enterprises of this profile. Therefore, improving the financial resources management is an urgent need of today.

Financial resources management of agricultural enterprises depends on a set of internal and external factors that cause direct or indirect influence. Thus, the effectiveness of financial management of agricultural enterprises depends on the prompt, rational and purposeful selection of appropriate management decisions to enhance incentives and avoid deterrent measures.

The introduction of an effective debt management system will enable the company to control the accounts payable, to repay them within the set time and to formulate a credit policy. In this case, the borrowed funds will be an additional and relatively cheap source of financing for the enterprise. Establishing a financial service will enable the agricultural enterprise to use its financial resources more efficiently and to solve problems that arise in the course of the enterprise's operation.

Стаття розкриває питання, які виникають у процесі управління сільськогосподарськими підприємствами. Демонструються методи і прийоми управління фінансовими ресурсами підприємства та їх удосконалення за допомогою планування, аналізу, бюджетування, кредитування. Розкрито сутність і важливість фінансової служби на сільськогосподарському підприємстві як окремого органу управління, яка бере на себе управління фінансовими потоками і вирішенням різних питань, пов'язаних з фінансовою діяльністю сільськогосподарського підприємства. Питання управління фінансовими ресурсами і удосконалення управління ними зараз $є$ досить актуальним питанням, яке цікавить не тільки науковців, але й власників приват- 
них підприємств, які шукають шляхи підвищення ефективності роботи своїх підприємств. Стосовно підприємств сільського господарства визначено, що діяльність цих підприємств має певні риси: нерівномірний характер виробництва, сезонність та динамічні зміни. Окремі регіони мають відмінності у наявності територіальних ресурсів, географії попиту, кількості підприємств даного профілю. Тому удосконалення управління фінансовими ресурсамиє нагальною потребоюсучасності.

Управління фінансовими ресурсами сільськогосподарських підприємств залежить від сукупності внутрішніх та зовнішніх факторів, які зумовлюють прямий чи опосередкований вплив. Таким чином, ефективність фінансового управління сільськогосподарських підприємств залежить від оперативного, раціонального та цілеспрямованого вибору відповідних управлінських рішень для посилення стимулюючих та уникнення стримуючих заходів.

Впровадження ефективної системи управління заборгованістю дасть можливість підприємству контролювати кредиторську заборгованість, проводити ї̈ погашення в установлені строки та формувати кредитнуполітику. Утакому випадкузалучені кошти будуть виступатидля підприємства додатковим та відносно дешевим джерелом його фінансування. Створення фінансової служби дасть змогу сільськогосподарському підприємству ефективніше використовувати фінансові ресурси і вирішувати проблеми, які виникають у процесі роботи підприємства.

Key words: financial resources, financial activity of enterprises, planning, analysis, lending.

КлючоВі слова: фрінансові ресурси, фонансоВа діяльність підприємств, плануВання, аналіз, кредитуВання.

\section{INTRODUCTION}

Financial resource management is a complex system of principles, techniques, methods and tools for influencing the formation and use of these resources. The current financial position of an agricultural enterprise and its role in a competitive market environment depends on the efficient management of its financial resources. Guided by a scientifically sound organization of the process of financial resources management of economic entities, its improvement is urgent, and as one of the priority factors for improving the efficiency of financial activities of agricultural enterprises. It is the managers of the enterprise who have complete and reliable information, so they are the ones who build the future of the enterprise.

\section{ANALYSIS OF RECENT RESEARCH}

The issue of improving financial resources management is a very topical task. Consideration of financial support and management of financial resources in agricultural enterprises is widely discussed in the scientific literature. Among the publications can be distinguished research such scientists as: Sabluk P., Vovk V., Nedilskaya L., Gudz O., Supihanov B., Kirilenko I., Demyanenko M., Mesel-Veselyak V., Laiko P., Stetsyuk P. and many other scientists.

Thus, Olena Yatsukh (2018) writes that the performance of any enterprise is conditioned both by the presence and quality of the fixed assets that support the process of its implementation. This issue is especially relevant for agricultural enterprises, as the rate of depreciation of fixed assets has fluctuated between 36 $42 \%$ in the last decade. The latter, accordingly, necessitates the search for financial resources for their updating. The low level of reproduction processes in agricultural enterprises is related to the violation of the basic principles of depreciation, price and investment policy. The author noted that, despite the profitable work of the industry, own funds for timely updating of fixed assets in agricultural producers are not enough, which is due to a number of reasons, among which the specificity of agrarian production, ie, the mismatch of the period of investment of funds and receipt of revenue from production, and a significant impact on these inflation processes, even in the short term. An important factor here is the lack of price parity for agricultural products and products of industries. It is quite difficult today to attract external financial resources through bank lending. This is due to both the unstable financial condition of many agricultural enterprises and, as a consequence, the low level of creditworthiness and the high interest rates.

Yatsenko O., Nitsenko V., Karasova N., James H.S.Jr., $\&$ Parcell J.L. (2017) argue that the conclusion of a free trade area agreement between Ukraine and the EU involves creating favorable conditions for future cooperation between specific countries or groups of countries. The powerful export potential of Ukrainian agriculture, as well as objective local and global changes in the markets for food and primary commodities, create opportunities for intensifying the trade and economic activity of Ukraine with the countries of the European Union in the context of granting a preferential trade regime. Regardless of the instability of the macroeconomic environment, Ukraine's agrarian sector is one of the few sectors of the economy that has demonstrated a positive foreign trade balance over the last 10 years, scientists say.

Therefore, the issues of improving the management of the financial resources of an agricultural enterprise are extremely urgent and need further investigation. 


\section{FORMULATING THE ARTICLE GOALS}

The purpose of this article is to find ways to improve the financial resources management in agricultural enterprises.

\section{RESULTS}

The financial resources of an agricultural enterprise are the means at the disposal of the enterprise and intended to fulfill certain financial obligations. And the management of financial resources is the process of using different methods to achieve certain goals of the enterprise, which includes: identifying the needs and sources of financial resources that must ensure the process of production and sale of products; determining the need for working capital; financial support for investments in the technical base, etc.; formation and distribution of funds from sales of products for the restoration of working capital, depreciation fund, gross and net income; formation, distribution and use of profit.

Improving the management of financial resources of enterprises is that the market economy is gaining momentum. Together with it, competition and gain as the main mechanism of regulation of the economic process is gaining momentum. The competitiveness of any business entity can only ensure the proper management of the movement of financial resources and capital at their disposal. To organize such management, you need to know the methodology and methodology of financial management, to be able to put into practice its techniques. Financial management, or the management of financial resources and relationships, encompasses a system of principles, methods, forms and techniques of regulation of a market mechanism in the field of finance in order to enhance the competitiveness of an entity.

In the process of managing the financial system of the enterprise the issues of obtaining, managing of financial resources and their use are solved. The basis of the activity of the production enterprise is production, and accordingly the movement of funds is determined by the movement of material resources. In other words, the industry features of the enterprise, its size, the length of the production cycle of production of products determine the structure and methods of financing a particular type of business activity. The financial resources of an enterprise are part of cash in the form of income and external revenues intended to fulfill financial obligations and expenses for the provision of extended reproduction.

Financial resources of the enterprise are formed as a result of production and economic activity of economic entities by obtaining money for the sold goods produced by them, as well as the mobilization of funds in the financial market. All this is reflected in the presence of a large number of cash flows, financial dependencies that form financial relationships. Their participants are:

- state bodies that own, manage and distribute state monetary resources resulting from payments and taxes, form state and local budgets;

- enterprises, institutions and organizations of all sectors and spheres of economy and entrepreneurship, which receive funds from the consumers of their products and spend the latter on the acquisition of factors of production, payment of taxes and accumulation;
- the population (families and individuals) who receive money from the state, businesses, entrepreneurs in the form of salaries, pensions, scholarships, assistance, gifts and spend it on the purchase of consumer goods and services and on savings.

Different authors propose different classification of financial resources of the enterprise depending on what factor underlies the analysis. So Blank I.A. offers the following classification:

1. By ownership, the financial resources formed by the enterprise are divided into two main types - own and borrowed. In the system of financial security management of the enterprise, such division of financial resources is decisive.

a) Own financial resources characterize the total value of an entity's cash and cash equivalents that are owned by them, that is, they form part of its equity.

b) Borrowed financial resources characterize the attracted capital of the enterprise in all its forms on the basis of return and payment. All forms of borrowed financial resources formed by an enterprise to carry out future economic activity represent its financial liabilities that are repayable in due time.

2. By groups of sources of attraction in relation to the enterprise allocate financial resources that are attracted from internal and external sources.

a) financial resources, attracted from internal sources, characterize their own part, which is formed directly at the enterprise to ensure its development. The basis of own financial resources, formed from internal sources, is the net profit of the enterprise.

b) financial resources, attracted from external sources, characterize the part that is formed outside the enterprise. It covers both equity and borrowing capital. The composition of this group of sources of formation of financial resources of the enterprise is quite numerous.

3. The following types of financial resources are allocated according to the time period of attraction:

a) financial resources raised on a long-term basis. They consist of the own financial resources of the enterprise, as well as of their loan types, which are attracted for more than one year. The aggregate of equity and long-term debt capital formed by the enterprise is characterized by the term "permanent capital". Financial resources attracted on a long-term basis are the main object of management of the process of their formation in the financial security of the enterprise.

b) short-term financial resources. They are formed by the enterprise for a period of up to one year. In financial security management, they are typically used to meet the temporary economic needs of an entity.

4. According to the level of satisfaction of the financial needs of the enterprise, the total amount of financial resources generated is divided as follows:

a) financial resources are not sufficient to fully meet the financial needs of the enterprise. This level of formation of financial resources does not allow to fully fulfill the main goal of financial security management - to create sufficient potential for sustainable growth of the enterprise in the future.

b) financial resources that fully meet the financial needs of the enterprise. This state of formation of financial 


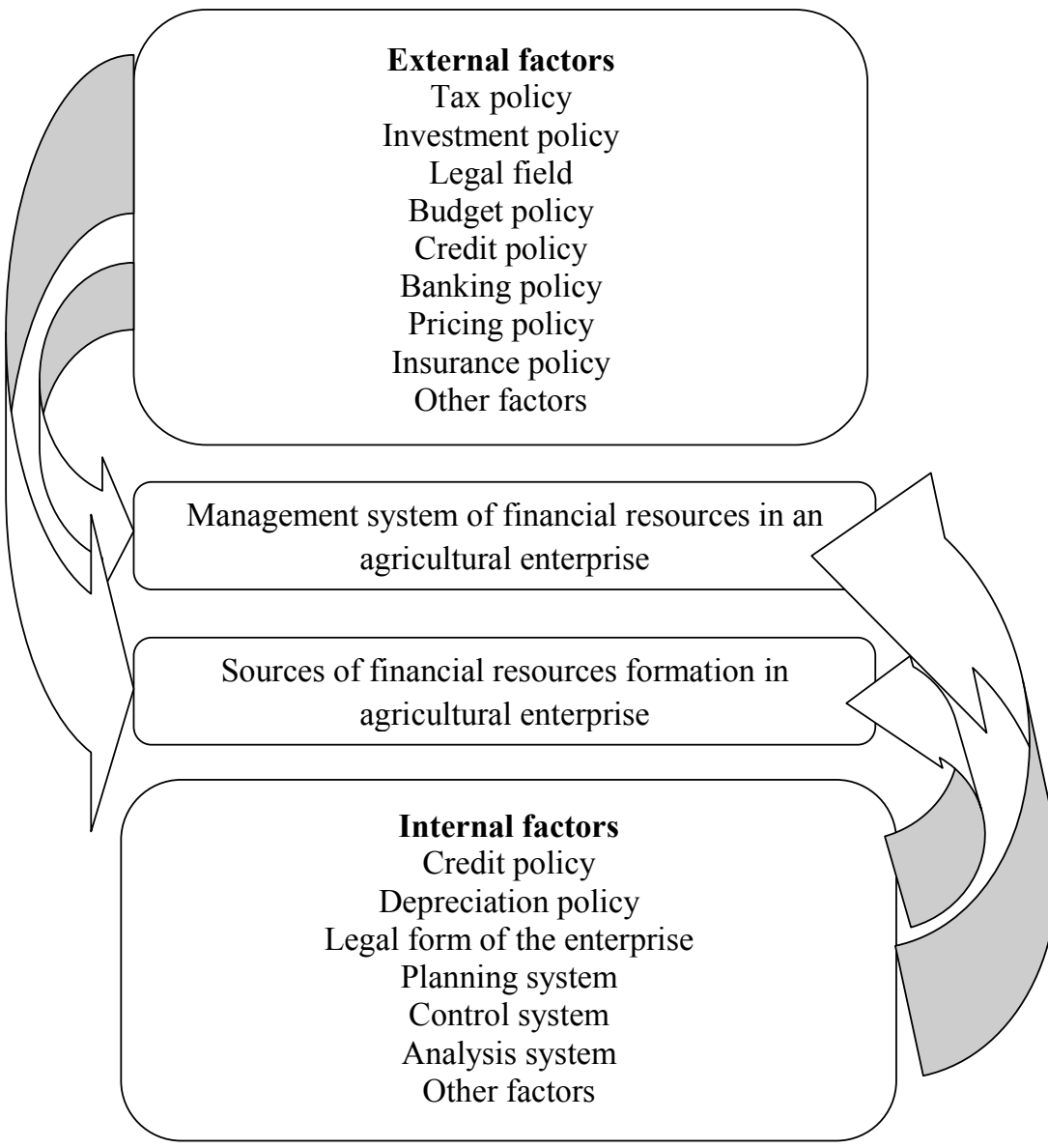

Fig. 1. Factors influencing the quality of financial resources management in agricultural enterprises

Table 1. Agricultural enterprises that received losses, \% of the total number of enterprises

\begin{tabular}{|l|l|r|}
\hline \multicolumn{1}{|c|}{ Year } & \multicolumn{1}{|c|}{ Millions UAH } & $\%$ \\
\hline 2009 & 6426,1 & 30,3 \\
\hline 2010 & 5014,3 & 30,5 \\
\hline 2011 & 5049,3 & 17,0 \\
\hline 2012 & 6914,0 & 21,7 \\
\hline 2013 & 11349,2 & 20,1 \\
\hline 2014 & 30493,6 & 15,8 \\
\hline 2015 & 25742,6 & 11,5 \\
\hline 2016 & 12832,7 & 12,2 \\
\hline 2017 & 20532,6 & 13,8 \\
\hline 2018 & 26404,6 & 13,8 \\
\hline
\end{tabular}

resources has their complete balance with the volume of financial needs of the enterprise.

c) financial resources that exceed the financial needs of the enterprise. This state of formation of financial resources is manifested in a number of cases when creating a new enterprise, in particular, a joint-stock company (when capital is formed taking into account the financial needs of the long-term perspective), or in the last stages of its life cycle (when the investment activity of the enterprise decreases). The considerable excess of financial resources over the need for them does not indicate a higher level of protection of the financial interests of the enterprise, as in this case the threats of loss of capital cost from inflation are realized in time.

Being guided by the scientifically sound organization of the process of financial resources management of an agricultural enterprise, its improvement is urgent, and is one of the priority factors for improving the efficiency of financial activity of agricultural enterprises, to ensure a high level of optimal management decisions.

There are some factors that influence the improvement of financial resources management. The starting factors for the process of financial resource management are the elements of macro and microenvironment, which cause a continuous impact on the activities of agricultural enterprises associated with the formation and use of resources. Macroeconomic factors play a prominent role in the system of financial resources management of agricultural enterprises. The current legislation, tax, credit, banking and insurance systems, pricing and investment policy are the main factors of external influence on the state of the availability of financial resources and their efficient use (Fig. 1). Their imperfection and contradiction now balance the volatile measures of internal financial management. At the same time, external factors have a decisive influence on the choice of internal control levers, and internal factors only encourage external management.

The legal field in the agrarian policy is formed by hundreds of legislative and by-laws, which are unstable, in most cases inactive or ineffective. This factor strongly influences the quality of financial resources management of agricultural enterprises.

In Table 1, we look at the dynamics of the share of agricultural enterprises that received losses.

Successful activity of the enterprise is not possible without effective management of financial resources. It is necessary to formulate goals that require the rational management of financial resources: survival in a competitive environment; ensuring the profitability of the enterprise; profit maximization; cost minimization; ensuring the profitability of the enterprise; bankruptcy prevention; leadership in the fight against competitors; growth in production and sales; maximizing the market value of the enterprise. Management of financial resources of the enterprise is carried out in such basic stages.

The first stage examines the total volume of financial resources formation, the correspondence of the growth rate of own and borrowed capital to the rate of growth of property and volume of sales of the enterprise, the dynamics of the share of own and borrowed resources in the total volume of formation of financial resources in the pre-planned period.

In the second stage of the analysis the sources of formation of financial resources are considered. First of all, the ratio of external and internal sources of financial resources formation, as well as the cost of attracting equity and borrowed capital from various sources is studied. 

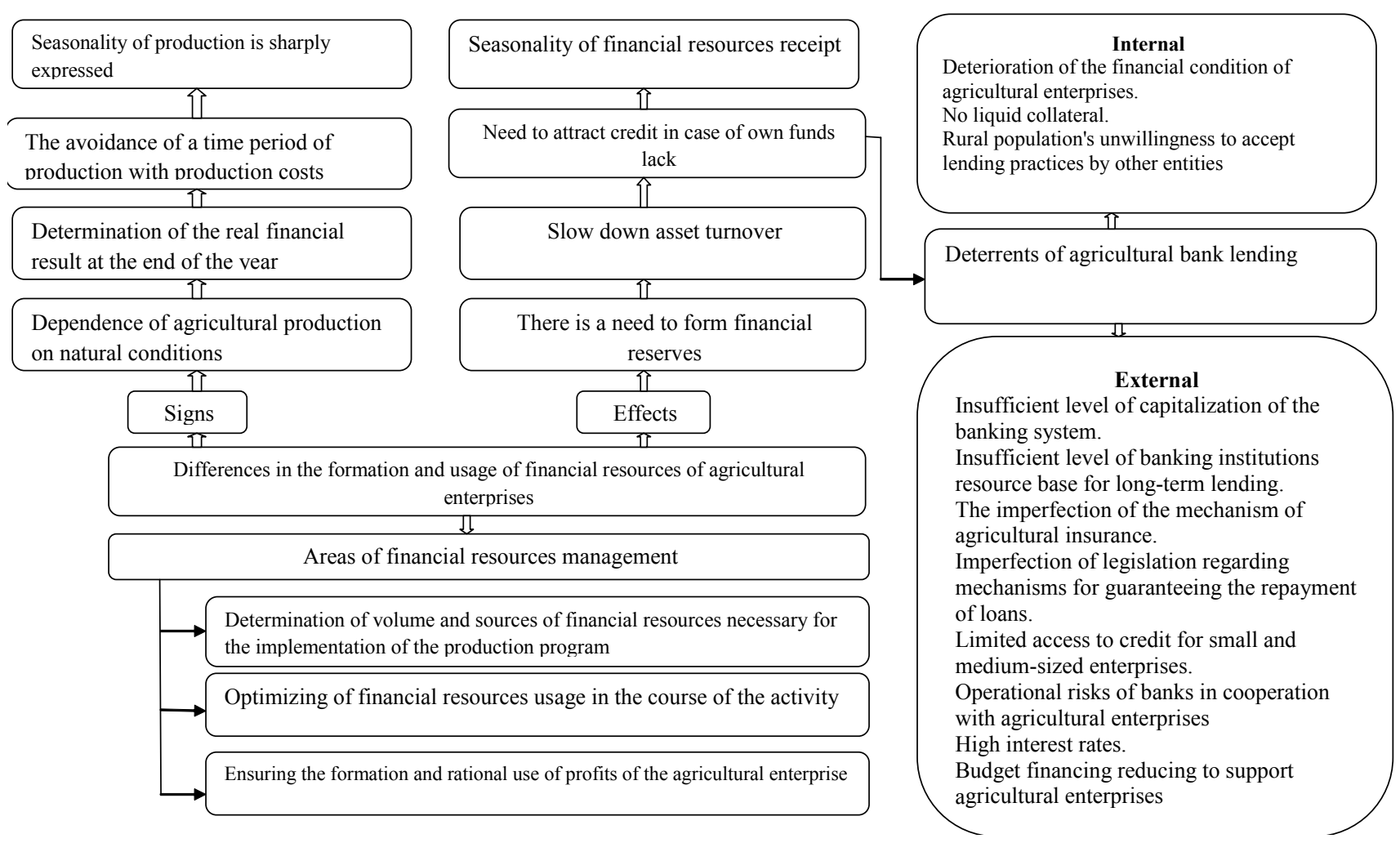

\section{Fig. 2. Signs of agricultural production and their impact on financial resource management}

The third stage of the analysis assesses the sufficiency of the financial resources generated by the enterprise in the reporting period. In the fourth stage, the ratio of internal and external sources of formation of own and debt financial is optimized.

In Fig. 2, agricultural production signs and their impact on financial resource management are grouped.

Management of financial resources on the basis of groups of management goals and objectives with clearly defined criteria will ensure a high level of making optimal management decisions. Thus, the management of financial resources should be based on the developed long-term financial policy, which sets goals and priorities for each level of management and stage of development of agricultural production. The system of diagnostics and optimization of financial resources management methods will allow economic entities to strengthen their financial position and position in the market environment. The main functions of the management process are planning, accounting, analysis, regulation. Planning is intended for formation of tasks of the enterprise; accounting - to obtain objective information about the state of the enterprise; analysis - to establish a diagnosis of the state of enterprises; regulation - to form alternative options for improving the condition of enterprises.

The directions of operational financial planning in the production activity of enterprises and the development of economic diagnostics and financial analysis for the operational management of financial resources have been substantiated, as well as the model of decision making on external financing based on the forecasted creditworthiness of the economy.

In the system of management of agricultural enterprises there are the following subsystems: planning of sources of formation and directions of use of financial resources for ensuring stable development of agricultural enterprise; analysis of financial statements and determination of agricultural enterprise solvency; control over the formation and efficient use of financial resources throughout the enterprise. The effectiveness of these systems depends on the quality of the decisions that are made and the efficiency of the enterprise.

The effective functioning of the management system at an agricultural enterprise depends, first of all, on the planning system, which should have a high degree of detail of the planning information comparable to accounting data. Formed into a management system based on the principles and methods of controlling, containing interconnected subsystems of financial and management accounting, planning, analysis and control allowed on the one hand to plan activities and evaluate the quality of decisions and plans made, on the other hand - to effectively monitor financially -economic activity.

Ways to improve the provision of financial resources to agricultural enterprises include: improvement of the planning and internal control system, the use of threshold standards, the acceleration of the circulation mechanism, the use of the evaluation mechanism of potential opportunities to increase profits, balancing financial flows with the use of instruments of state regulation, optimization of tax and dividend system, risk management, improvement of the system of calculations and payments. This will allow you to find and use reserves to improve the efficiency of the enterprise.

Planning the finances of an enterprise is a process of drawing up, adopting and executing financial plans, which is aimed, on the one hand, to prevent erroneous actions in the activity of the enterprise, on the other - to reduce 
the number of unused opportunities. The main document of the financial plan of the enterprise is the balance of income and expenses of the enterprise. The system of operational planning of financial activity is to develop a set of short-term planned tasks for the financial support of the main areas of financial and economic activity of the enterprise. Operational financial planning is necessary for the enterprise to control the actual flow of funds into the current account, the expenditure of funds in the course of economic activity, the implementation of the current financial plan.

One of the effective mechanisms of current planning and management of an enterprise in a market environment is budgeting, which combines a set of methods, the implementation of managerial influences, means of gathering and processing information, motivation techniques, the control system of budgeting, in our opinion, is management technology. Budgeting is characterized by a multiplicity of budgets, the set of which for each enterprise is individual and is determined by the scope of production, the peculiarities of financial and economic activities, the goals of organizing the budgeting system. The main factors that determine the feasibility of introducing budgeting as a management system for agroindustrial enterprises, in our opinion are: the dynamics of market conditions and riskiness of agricultural production, multi-sectoral nature, complex organizational structure of agricultural enterprises and the need to reduce management costs.

The current situation is forcing business entities to look for new ways to optimize their activities. Most operating businesses in recent years do not boast sufficient profitability, and increasingly increase payables. This fact is an indicator of increased activity of business entities in the market, which leads to a significant increase in liabilities over debt. However, borrowing is, in the main, not aimed at restructuring production, but rather at repaying its obligations to other creditors.

Modeling of agricultural production allows predicting the most optimal ratios of industries in the agricultural enterprise and its specialization, which must meet the existing demand for products with the fullest use of all types of resources of the economy. The level of financial and credit support is significantly influenced by the efficiency of agricultural production. Adequate levels of money supply make it possible to fully adhere to agricultural production technology, which ultimately affects production efficiency. Today, debt management is an important area of organization of financial management in the enterprise, because it can be the basis of support of modern business. The value of payables lies in its ability to transform into an additional and relatively inexpensive source of attracting resources.

If an entity is not managing its liabilities well enough, then accounts payable will "work" against the enterprise as its growth will cause its financial condition to deteriorate.

Therefore, it is necessary to constantly develop and implement measures to improve the management of accounts payable, namely:

1. Optimization of accounts payable.

2. Constant control of the turnover of funds in the calculations.
3. Carrying out the selection of potential buyers and determining the terms and forms of payment for the goods stipulated in the contracts and contracts.

2. Constant control of the turnover of funds in the calculations.

3. Carrying out the selection of potential buyers and determining the terms and forms of payment for the goods stipulated in the contracts and contracts.

4. Carrying out the selection of buyers by informal criteria: the level of current solvency of the client, compliance with the payment discipline, projected financial capabilities, financial and economic capacity of the enterprise.

5. Application of the practice of shipment of goods on credit to regular buyers, it can be envisaged providing a small discount when paying in the first days of the crediting period, and in case of non-payment timely establish financial sanctions, the value of which will increase every day.

6. Ranking of accounts payable by maturity. At the same time it is necessary to ensure constant control of bad debts for timely creation of the necessary reserve.

7. Organization of work with debtors in order to optimize accounts receivable and increase as a result own funds for financing the activity of the enterprise, which will help to reduce the share of accounts payable.

8. Constant analysis of the level of all types of debt and determination of their critical level

9. Compliance with the economically sound level of the ratio between accounts payable and accounts receivable.

10. Construction of analytical accounting to ensure receipt of data on the maturity date, the formation of delays, the availability of bills, which will prevent the occurrence of unreasonable debt.

11. Constant monitoring of the status of payments on time.

12. Expansion of the system of advance payments (in the context of inflation, any delay in payment leads to the fact that the organization actually receives only a part of the cost of the work performed);

13. Timely identification of unacceptable types of accounts payable (overdue budgetary arrears, etc.). It is important to emphasize the importance of the financial department in an agricultural enterprise.

For a long time in the domestic practice, the financial services of firms were not independent; their work was limited to servicing calculations using strictly defined forms, drawing up elementary financial plans and reports that have no real impact. The real impact was only the work of accounting, that is, it was advisable to combine financial work with accounting.

This practice of finance organization has existed and still exists in most enterprises. But the manager of the company should take into account that at the same time to be a good accountant and a good financier cannot. It is the managers of the enterprise who have complete and reliable information, so they are the ones who build the future of the enterprise. The Financial Service solves a number of problems that arise when managing finances, such as: drawing up financial plans; crisis management; cost management; cash shortages; cash flow management, etc. 


\section{CONCLUSIONS}

Financial resources management is part of the overall financial strategy of the enterprise, which is to provide the necessary level of financing for its productive development.

Financial resources management in agricultural enterprises depends on a set of internal and external factors that cause direct or indirect influence. Thus, the effectiveness of financial management of agricultural enterprises depends on the prompt, rational and purposeful selection of appropriate management decisions to enhance incentives and avoid deterrent measures.

The introduction of an effective debt management system will enable the company to control the accounts payable, to repay them within the set time and to formulate a credit policy. In this case, the borrowed funds will be an additional and relatively cheap source of financing for the enterprise. Establishing a financial service will enable the agricultural enterprise to use its financial resources more efficiently and to solve problems that arise in the course of the enterprise's operation.

\section{Література:}

1. Демчук Н.І., Халатур С.М., Хідірян М.О. Теоретичні основи аналізу фрінансового стану сільськогосподарських підприємств / / Економіка та суспільство. 2017. - 9. - С. 396-400.

2. Колеснік Я.В., Криворучко А.О. Перспективи розвитку фрінансового менеджменту у сфрері споживчого та іпотечного кредитування / Я.В. Колеснік, А.О. Криворучко / / Міжнародний науково-практичний журнал "Економіка та держава". - Київ, 2018. - № 11 (листопад). - С. 77-80.

3. Колеснік Я.В., Чорний В.О. Стратегія розвитку податкового менеджменту сільськогосподарських підприємств / Я.В. Колеснік, В.О. Чорний / / Науковопрактичний журнал "Інвестиції: практика та досвід". Київ, 2018. - № 21 (листопад). - С. 55-59.

4. Крючко Л.С. Розвиток інноваційної діяльності сільськогосподарських підприємств регіону // Вісник Запорізького національного університету, Серія: Економічні науки - 2011. - № 4 (12). - С.158-162.

5. Крючко Л.С. Перспективи піднесення аграрного сектору України в умовах фрінансової глобалізації ринку продовольства / / Науково-практичний журнал "АгроСвіт". - 2013. - № 15. - С.30-35.

6. Bestuzheva S.V. (2015). Foreign Trade Development Directions in the Agriculture of Ukraine. Global and National Economic Problems, 4, 41-45.

7. Hudym K., Khalatur S. (2016). Systematisation and analysis of MNCs' models of conduct for entering the national agrarian markets / Економічний часопис-XXI, № 5-6, 34-37.

8. Khalatur S. (2015) Mechanism of adaptation of agroindustrial complex of Ukraine in the conditions of global food problem / / Visnyk Dnipropetrovs' koho derzhavnoho ahrarno-ekonomichnoho universytetu, 1, 114-116.

9. Khalatur S.M. (2017). Innovative doctrine development of agriculture growth of Ukraine // Технологический аудит и резервы производства. Vol. 4, 5 (36), 19-26.

10. Official website of the State Statistics Committee. URL: www.ukrstat.gov.ua
11. Yatsukh O. (2018). Cognitive modeling of factors of influence on the processes of formation and reproduction of fixed assets of agricultural enterprises / / Development Management, 16 (4), P. 73-87. doi:10.21511/dm.4(4).2018.07

12. Yatsenko O., Nitsenko V., Karasova N., James H.S.Jr., $\&$ Parcell J.L. (2017). Realization of the potential of the Ukraine-EU free trade area in agriculture / / Journal of International Studies, 10 (2), pp. 258-277. doi:10.14254/ 2071-8330.2017/10-2/18

\section{References:}

1. Demchuk, N.I. Khalatur, S.M. and Khidiryan, M.O. (2017), "Theoretical bases of analysis of the financial state of agricultural enterprises", Economics and Society, vol. 9, 396- 400 .

2. Kolesnik, Y.V. and Kryvoruchko, A.O. (2018), "Prospects of financial management development in the sphere of consumer and mortgage lending", Economy and State, vol. 11, pp. 77-80.

3. Kolesnik, Y.V. and Cherniy, V.O. (2018), "The strategy of development of tax management of agricultural enterprises", Investments: Practice and Experience, vol. 21 , pp. $55-59$.

4. Kryuchko, L.S. (2011), "Development of innovative activity of agricultural enterprises of the region", Bulletin of the Zaporizhzhya National University, Series: Economic Sciences, vol. 4(12), pp.158-162.

5. Kryuchko, L.S. (2013), "Prospects of raising the agrarian sector of Ukraine in the conditions of financial globalization of the food market", AgroSvit, vol. 15, pp. $30-35$.

6. Bestuzheva, S. V. (2015), "Foreign Trade Development Directions in the Agriculture of Ukraine", Global and National Economic Problems, vol. 4, pp. 41-45.

7. Hudym K., Khalatur S. (2016). Systematisation and analysis of MNCs' models of conduct for entering the national agrarian markets. Economic Annals -XXI, 5-6, $34-37$.

8. Khalatur, S. (2015), "Mechanism of adaptation of agroindustrial complex of Ukraine in the conditions of global food problem", Visnyk Dnipropetrovs' koho derzhavnoho ahrarno-ekonomichnoho universytetu, vol. 1, pp. $114-116$.

9. Khalatur, S.M. (2017), "Innovative doctrine development of agriculture growth of Ukraine. Technological audit and production reserves", vol. 4,5 (36), pp. $19-26$.

10. Official website of the State Statistics Committee (2019), available at: www.ukrstat.gov.ua (Accessed 15 Oct 2019).

11. Yatsukh, O. (2018), "Cognitive modeling of factors of influence on the processes of formation and reproduction of fixed assets of agricultural enterprises", Development Management, 16 (4), 73-87. doi:10.21511/ dm.4(4).2018.07

12. Yatsenko, O. Nitsenko, V. Karasova, N. James, H.S.Jr. and Parcell, J.L. (2017), "Realization of the potential of the Ukraine-EU free trade area in agriculture", Journal of International Studies, vol. 10 (2), pp. 258-277. doi: $10.14254 / 2071-8330.2017 / 10-2 / 18$

Стаття надійшла до редакцї̈ 26.10.2019 p. 